\title{
PROVIDENTIA FOR THE WIDOWS OF 1 TIMOTHY 5:3-16
}

\author{
B. W. Winter
}

It was not only in Acts 6:1-5 that providing for the widows caused problems for the newly established Christian Ek $^{\prime} \lambda \eta \sigma l \alpha$. Similar problems were encountered in another congregation where they were 'a disruptive force', to cite the observation of S. Humphries on 1 Timothy 5:3-16. ${ }^{1}$ Sorting out widows was not only a pastoral headache in the early church, it has also proved to be an exegetical one for modern commentators. ${ }^{2}$ Discussion of this passage has not been directed towards the important issue of the legal stipulations and social conventions surrounding widows and their support in the Graeco-Roman world. ${ }^{3}$ This article seeks to clarify certain puzzling aspects of 1 Timothy 5:3-16 within that legal and social context. ${ }^{4}$

\section{Legal Providentia}

The dowry which always accompanied a woman to her marriage constituted an important legal aspect of marriage. Greek marriage contracts specified the nature and value of the dowry and continued to do so in the Roman period. "The only legal obligation that the groom acquired toward the wife upon

1S.C. Humphries, The Family, Women and Death: Comparative Studies (London, Routledge and Kegan Paul 1983) 47.

2 E.g. D.C. Verner, The Household of God: The Social World of the Pastoral Epistles, SBL Diss. Series 71 (Chico, Scholars Press 1983) 161-66 and J.M. Bassler, 'The Widows' Tale: A Fresh Look at 1 Tim.5:3-16', JBL 103 (1984) 23-41.

${ }^{3}$ Of the array of commentaries consulted E.K. Simpson, The Pastoral Epistles (London, Tyndale Press 1954) 73 refers to the Greek legal requirements of children to support their parents in Athens, but none make mention of the issue of the dowry for which legal stipulations existed concerning widows. See n. 6

4 I am grateful to J.A. Crook, Emeritus Professor of Ancient History, Cambridge University for the suggestion that the solution to some issues in this passage might well rest in Graeco-Roman law. The support of the Tyndale House Council, the Witness Foundation and the Jubilee Foundation is acknowledged for the research on this paper. 
receipt of the dowry was her maintenance'.$^{5}$ In the event of her husband's death the laws governing that dowry were clearly defined. ${ }^{6}$ A widow was cared for by the person in charge of that dowry. Two options were open to her. If she had children, she could remain in her deceased husband's home. There she would be maintained by the new kúplos of the household, possibly her son. She could also return to her parents taking her dowry back to her family. ${ }^{7}$ The returning of that dowry meant the legal severance from her late husband's household. 8 The rules which governed the repayment of the dowry were enforced by $\delta / \mathrm{km} \pi$ moukos and those dealing with the interest rate to be charged on the value of the dowry from the time of the husband's death until its return were covered by $\delta(\kappa \eta$ ol tov. ${ }^{9}$ The dowry's 'basic object was to provide for the maintenance of the woman'. ${ }^{10}$ W.K. Lacey notes 'the law was explicit; the person who had charge of her dowry had the obligation to maintain her'.11 It was a legal obligation. ${ }^{12}$

${ }^{5}$ D.M. Schaps, Economic Rights of Women in Ancient Greece (Edinburgh, University Press 1979) 75.

${ }^{6}$ D.M. Schaps, 'The Dowry' op.cit. ch.6 and appendices for an excellent discussion of the dowry and issues of its inheritance on the husband's death; and A.R.W. Harrison, The Law of Athens: Family and Property I (Oxford, Clarendon Press 1968) 145-60. See also R. Taubenschlag, The Law of GrecoRoman Egypt in the Light of the Papyri 332 B.C - 640 A.D. (Warsaw, Panstwowe Wydawnictwo Naukowe 1955) 120-7 for evidence of the continuation of this through the Hellenistic and Roman periods. For examples of extant marriage contracts all of which refer specifically to the contents or value of the dowry and its importance see $P$ Ryl 154 (AD 66) 'received from him as a dowry on his daughter', P Eleph 1 (311 BC) P Tebt 104 (92 BC), BGU 1052 (13 BC), cited in A.S. Hunt and C.C. Edgar, Select Papyri I (London and Cambridge Mass. 1970). On the Roman side see J.P.V.D. Balsdon, Roman Women: Their History and Habits (London, Bodley Head 21974 ) 186-9 where the recovery of a dowry in part or whole was for its future use i.e. remarriage.

${ }^{7}$ A.R.W. Harrison, op.cit. I, 38, 57.

8 Just as the dowry set up the marriage, A.R.W. Harrison, op. cit. I, 45 its return of it saw the termination of the relationship, S.C. Humphreys, op.cit. 46 citing BGU 1104 (I BC).

${ }^{9}$ A.R.W. Harrison, The Law of Athens: Procedures, II (Oxford, Clarendon Press 1971) 22.

${ }^{10}$ A.R.W. Harrison, op.cit. I, 57.

${ }^{11}$ W.K. Lacey, The Family in Classical Greece (London, Thames and Hudson 1968) 117.

${ }^{12}$ D.M. Schaps, op.cit. Appendix IV. 
In Athens there was not only a moral but also a legal obligation placed upon children to care for both parents, and failure to do so rendered one liable to prosecution in which 'the prosecutor ran no risk of punishment' ${ }^{13}$

The Roman woman had similar security and had what S. Dixon describes as 'a dowager's life interest in her husband's holdings' based on the understanding that she would at death pass it on to children from that issue. ${ }^{14}$ The Hellenistic Jewish position according to Falk allowed the wife hold in her own property during marriage, and when made a widow, to retain part of her dowry. ${ }^{15}$

It was expected in the ancient world that a widow would remarry. Augustus in the lex Papia Poppaea of AD 9 actually legislated for this after a husband's death if she were still of child-bearing age, i.e. under fifty. ${ }^{16}$ The period during which she could remain a widow was finally set at two years. This was the legal position for Roman citizens in the first century but not apparently observed by all. ${ }^{17}$ There was also a very strong conviction that the Greek woman would remarry 'so that she be not left a widow', a thought abhorrent to the Greeks. ${ }^{18}$ 'There can be little doubt, that young widows, even if they had children, were expected to remarry', for remarriage provided a secure option for the younger widow. ${ }^{19}$

The Graeco-Roman world sought to make sure that widows had security either by sheltering in the ofkos of the sons of her late husband or in that of her parents with her

${ }^{13}$ Furthermore all who aspired to public office were asked 'Do you treat your parents well?', W.K. Lacey, op.cit. 116-18.

${ }^{14}$ S. Dixon, The Roman Mother (London and Sydney, Croom Helm 1988) 47.

${ }^{15}$ Z.W. Falk, Introduction to Jewish Laws of the Second Commonwealth (Leiden, E.J. Brill 1978) 290.

${ }^{16} \mathrm{~A}$. Wallace-Hadrill, 'Family and Inheritance in the Augustan Marriage Laws', Proceedings of the Cambridge Philological Society (n.s.) 27 (1981) 59; see also J.F. Gardner, Women in Roman Law and Society (London and Sydney, Croom Helm 1986) 178-9.

17B. Rawson, 'The Roman Family', The Family in Ancient Rome: New Perspectives ed. B. Rawson (London and Sydney, Croom Helm 1986) 31.

${ }^{18}$ D.M. Schaps op.cit. 41 and sources cited $127 \mathrm{nn} .105-6$.

${ }^{19}$ W.K. Lacey, op.cit. 108. 
dowry. As Schaps comments Legally, then, a woman was never as thoroughly protected as she was in her old age'.$^{20}$

However worthy the legal intentions were there were always those who slipped through the net, especially those at the lowest end of the economic scale. ${ }^{21}$ The church saw itself responsibility for Christian widows who were from this group and unable to support themselves financially, 1 Timothy 5:16. In order to fulfil this role there was the need to lay down who were its 'real' widows and to exhort individual congregational members to assume or resume legal and filial responsibility for their relatives bereft of their husbands.

\section{Trends in Providentia in the City}

There were societal conventions whereby food was distributed to meet a city-wide crisis. ${ }^{22}$ These ad hoc arrangements were for emergency situations only. ${ }^{23}$ The distribution of basic provisions by a wealthy member or members of a city in time of famine or general food shortage was not motivated by pity for the poor and destitute among whom were widows. ${ }^{24}$ Fear of riots and city strife with possible loss of personal property often prompted the rich to stave off food riots by means of food distributions or manipulation of the market to force down the price of essential commodities in time of dearth. ${ }^{25}$ In contrast the Jewish synagogues had a permanent

20 Op.cit. 84.

${ }^{21}$ A.R. Hands, Charities and Social Aid in Greece and Rome (London, Thames and Hudson 1968) 71-3.

${ }^{22}$ See most recently, P. Garnsey, Famine and Food Supply in the Graeco-Roman World: Responses to Risk and Crisis (Cambridge, Cambridge University Press 1988).

${ }^{23}$ The only administrative provision was the appointment of a curator annonae to be in charge of the grain supply when such need arose. He was expected as part of this liturgy to use his own resources or persuade others to act as public benefactors in return for customary civic honours, G. Rickman, The Corn Supply of Ancient Rome (Oxford, Clarendon Press 1980) 218-25.

24 One only gave to those who could could make some return or be of some advantage to the giver see 'Giving for a Return', A.R. Hands, op.cit. ch. 3.

${ }^{25}$ For a discussion of this role by benefactors see P. Garnsey, op.cit. 82-6 and its possible application in the N.T. see the author's, 'The Public Praising of Christian Benefactors: Romans 13:3-4 and I Peter 2:14-15', forthcoming JSNT 1988. 
organization for the needy with the weekly distribution to the sojourner and the resident poor including the widows. ${ }^{26}$

There was the tradition in the East of free meals at some endowed festivals. Distributions in a city would commemorate citizens who acted as benefactors. They had bequeathed funds which were made possible such handouts or feasts. ${ }^{27}$ These were given to those 'worthy of honour', and even if a benefactor had stipulated a distribution to all the citizens, the former still received larger proportions. ${ }^{28}$ To belong to a group with status bestowed benefits such as this. Distribution was not based on need.

There was the long standing right of Roman citizens living in the capital to receive the monthly corn dole regardless of need. ${ }^{29}$ There the head of households found a convenient loophole. They made slaves freedmen, giving them a change of status in the household but of course stipulating at the point of manumission their obligations to live with their masters continuing to undertake their normal duties. ${ }^{30}$ 'Gradually during the century after Augustus' death new categories of recipients seem to have been admitted to the frumentum publicum.'31 Coins were struck with the emperor feeding Rome and the term providentia was one the Principate was happy to use as a description of one of the functions of this office. ${ }^{32}$

${ }^{26}$ K.F. Nickle, The Collection: A Study in Paul's Strategy, SBT 48 (London, SCM 1966) 93-4.

27 A.R. Hands, op.cit. 89-94.

${ }^{28}$ A.R. Hands, op.cit. 91 and 94 and ch. VI 'Pity for the Destitute'.

29 For the most recent discussion see P. Garnsey, op.cit. 238 and ch. 14 and G.

Rickman, 'The Corn Distribution', op.cit. ch. vii.

${ }^{30} \mathrm{G}$. Rickman, op.cit. 189.

${ }^{31}$ G. Rickman, op.cit. 189 and K. Hopkins, Conquerors and Slaves, Sociological Studies in Roman History I (Cambridge, Cambridge University Press 1978) 14158.

${ }^{32}$ Claudius struck small coins at the beginning of his reign with two corn ears in the right hand and the legend Ceres Augusta S.C., As G. Rickman, op.cit. 260-1 says, 'The message was clear, the new emperor cared'. Nero produced his famous sestertius showing himself provisioning Rome and this propaganda was followed by Vitellius, Vespasian, Titus and Domitian. On the use of the term providentia or $\pi p$ ovola as one of the chief attributes of good emperors 'to care for the life of the state' see C.P. Charlesworth, 'Providentia and Aeternitas', HTR 29 (1936) 107-32. 
There was also the provision of child allowances, alimenta, which appear to have operated in some places in the empire from at least the time of Nero onwards, although Augustus appears to have created something of a precedent by including minores pueri among his congiari. Resources for this allowance were raised from public benefactors and were private schemes in the first century AD. ${ }^{33}$

Reactions to concessions show that there were always those on the look-out to exploit them financially. ${ }^{34}$ While a 'welfare' syndrome was not unknown in the first century, it would be wrong to see the Roman government consciously travelling down that road. ${ }^{35}$ However, what is clear is that the shifting of the responsibility for the provision of the needs of some members of one's household on to another provider was always welcome. 1 Timothy 5:3-16 appears to be dealing with a similar attitude where some widows, if not all, were not being supported by the heads of their households, but by the church. Its resources were stretched far too thinly to meet adequately the needs of the widow who was without a family. 'Let the church be not burdened, so that it may assist those who are real widows' v.16. Hence there was the urgent need to reorganize the system for the proper care of the widows.

\section{Providentia in the Jerusalem Church}

The adoption by the Jerusalem Church of the procedures of the synagogue in the charitable distributions to Jewish widows appears to have occurred almost from the

${ }^{33}$ A.R. Hands, op. cit. 108 and Document 19 for the text.

${ }^{34}$ For another example see the tax and liturgy exemptions granted by Vespasian to teachers and the rescript of Domitian to restrain abuses arising from the concession: M. McCrum and A.G. Woodhead, Select Documents of the Principates of the Flavian Emperors A.D. 68-96 (Cambridge, Cambridge University Press 1966) No.458.

35P. Garnsey, op.cit. 276. 'However, the extent of the intevention of the imperial state in civil society can be exaggerated. Provincials were expected to help themselves, and they did so in the time-honoured ways...In the cities euergetism continued to be the main shield of the common people against adversity.' 
beginning of former's inception. ${ }^{36}$ In the synagogues every Friday weekly distributions were made to the poor from the money chest. Among the recipients were the widows. ${ }^{37}$ The Jerusalem church followed suit, but with a daily distribution. The reason for this adjustment is not explained but it may be related to its daily corporate activity described in Acts 2:46 as against the weekly gatherings in the synagogues. The synagogue's tried and tested method of collection and distribution proved to be the appropriate model to use to fulfill the injunctions of Jesus to meet the needs of the poor whom the church found only too readily to be 'always' with them.

The apostles who initially assumed the role of the receivers and distributors of alms in the synagogue drew sharp criticism from the Hellenists because of allegations of the neglect of the latter's widows in the distribution. Arrangements that suited a smaller $\epsilon^{2} \kappa \kappa \lambda \eta \sigma l \alpha$ apparently proved to be unsatisfactory with an increasing number of disciples coming into the Christian community, including widows, Acts 6:1a. The N.T. gives no further indications that the mechanism for distribution to the poor in Jerusalem needed subsequent adjustments. It does however reveal that the problem continued to be a lack of resources from within the Jerusalem church. Only collections from the Diaspora Jewish and Gentile Christians saved them from destitution especially in a time of famine, Acts 11:27-30. ${ }^{38}$

Was the church's administrative procedure for the distribution in Jerusalem simply taken over by the congregation of 1 Timothy and hence the problems which arose of all widows becoming eligible for the distribution? If there were modifications among Gentile churches of the Christian distribution system of the Jerusalem $\epsilon_{\kappa \kappa} \lambda \eta \sigma / \alpha$ which took account of the social ethos of the secular community from which converts came

${ }^{36}$ E. Schürer, The History of the Jewish People in the Age of Jesus Christ II (Edinburgh, T \& T Clark 1979) 437 n.45 who notes that the 'officers charged by

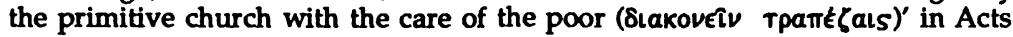
6:1-5 are fulfilling an identical role.

37 Ibid. and K.F. Nickle, op.cit. 93-4.

${ }^{38}$ Acts 24:17 and 1 Cor 16:1f., 2 Cor 8-9 and Rom 15:25-27 although in these instances there is no indication of the famine situation referred to in Acts 11:2730. 
it is difficult to determine what they were because of insufficient evidence. ${ }^{39}$ Certainly the impression is given that the injunctions in 1 Timothy 5:3-16 aimed to modify the existing procedures which apparently had no means test. ${ }^{40}$

\section{Providentia by Children and Grandchildren}

In 1 Timothy 5:4 the matter of religious duty is spelt out for children and grandchildren. The households of converts were to be the first place where $\epsilon \dot{v} \sigma \epsilon \beta$ l $\alpha$ was expressed in practical help to the resident widows. It was to be seen as the first place where the primary lesson in $\epsilon \dot{U} \sigma \epsilon \beta l \alpha$ was to be

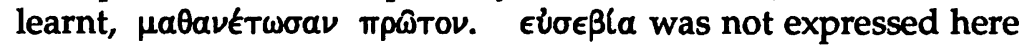
in worship in church or personal piety, but in the household. For the Christian church it was the first commandment 'with a promise' ${ }^{41}$

This filial piety was seen in financial terms in $\mathrm{v.4b.} \mathbf{4 2}$ Christians were told that they were under a clear obligation to support the widow as compensation for the care and financial cost formerly expended upon children and grandchildren when they were young, v.4b. In a society where the meeting of obligations was of paramount importance, failure to do so would have constituted a very serious breach indeed. This injunction is further supported by the statement that this conduct is acceptable in the sight of God, v.4c. ${ }^{43}$

In v.8.a there is reference to those who sought to avoid

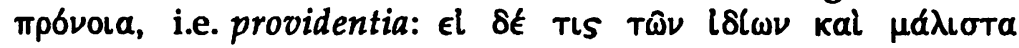

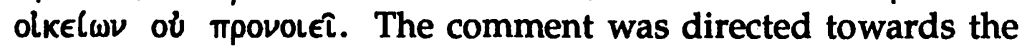
kuplos or kúplol of the Christian olkol. There is a diversity of

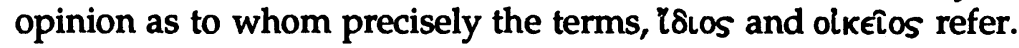
Commentators have regarded $\mathrm{l} \delta \mathrm{i}, \mathrm{s}$ in $\mathrm{v.8}$ as a reference to

${ }^{39}$ The only other citing of the commandment of Exodus 20.12 'to honour' in Eph.6.1-2 was for the purpose of securing obedience. There is no explicit reference to widows per se.

${ }^{40} \mathrm{~J} . M$. Bassler, op.cit. 34 citing in support J. Müller-Bardorff, 'Zur exegese vom 1 Timotheus 5,3-16', Gott und die Götter: Festgabe für Erick Fasher zum 60. Geburtstag (Berlin, Evangelische Verlagsanstalt 1958) 113-33.

${ }^{41}$ Eph 6:2 citing Ex 20.12.

${ }^{42}$ C. Spicq, Les Épitres Pastorales, Etudes Bibliques (Paris, Gabalda 41969$) 525$.

43 TODTo refers back to the imperatives in that verse. 
either slaves and freedmen or one's relatives in general, while olkeivos could refer to either blood relatives or members of one's immediate family. 44

Verse 8 r $\delta$ เo could be a general reference to those belonging to a household and could encompass one's freedmen who may not necessarily live at home, but to whom one had obligations, especially if he were to find himself impoverished. The attempt to avoid providentia for one's slaves by making them freedmen was certainly a known reason for granting manumission. ${ }^{45}$ It enabled the slave owner to continue to have his services but without the cost of his upkeep. Slaves so manumitted took responsibility for finding their own lodgings. If totol covers those belong to this group to whom there were still obligations by the kúpios, then it would follow that olkeîl refers specifically to the family who lived at home, and among them was the widow who was residing with the kuplos of the dowry. 46

If in v. 8a tolo is a reference to widows, then the term would refer to widows who were not living at home. 47 The ktplot had a Christian responsibility towards them based on the Decalogue. olkeîs would still refer specifically to the widow who was residing at home and for whom legal responsibility has been assumed with the acceptance of the dowry. There was then a special legal obligation towards a

${ }^{44}$ E.g. C. Spicq, op.cit. 531, J.N.D. Kelly, A Commentary on the Pastoral Epistles (London, A\&C. Clark 1963) 114-15, and D.C. Verner, op.cit. 138. for a summary of opinions.

${ }^{45}$ The Lex Aelia Sentia of AD 4 required a patron on pain of losing the right to the operae to furnish food for his freedman. This is generally interpreted to mean that 'he had to prevent a freedman from dying of starvation, just as a freedman had to support his patron if he had fallen into need', A.M. Duff, Freedmen in the Early Roman Empire (Oxford, Clarendon Press 1928) 48. S. Treggiari, Roman Freedmen during the Late Republic (Oxford, Clarendon Press 1969) 16 'the freedman would usually support himself, taking the burden of finding food and lodging from the shoulders of his patron'.

${ }^{46} X$ @pis olkoUvtes refers to those who were not part of their master's household in the narrow physical sense according to A.R.W. Harrison, op.cit. I $167 \mathrm{n} .5$.

${ }^{47}$ D.C. Verner, op.cit. 138 rightly sees that this possibility is difficult to explain as widows away from home 'would be in greater danger of neglect'. However, if the responsibility for the dowry was assumed by another,then the statement is explicable as it applies to widows living away from those Christian household being addressed in v.8. Verner's objection thus disappears. 
widow living at home and a less committing obligation towards one residing away from the household. As the overall context of vv.3-16 is the issue of widows, it is suggested that totol refers to those widows residing away from the household. Children and grandchildren were being called upon to accept full financial responsibility for olkeiol. The number of widows in a family household could be more than two. ${ }^{48}$

The condemnation of the kuplo in v. $8 b$ is twofold. One relates to the O.T. commandment and the other to the legal situation outlined above.

First, in $v .8 b$ there is the serious charge of the denial of the faith, in $\pi$ loTtS, which encompassed the important commandment to children to honour their parents, but which the church shouldered when there were no others to fulfil it, v.16. The use of the imperative $\tau$ i $\mu \mathrm{a}$ in $v .3$ indicates that it is the Fifth Commanment from the Decalogue that rests behind the discussion. This avoidance of $\pi \rho$ óvola by the rúplos was seen as a denial of the faith by those who had widowed mothers and grandmothers. It comes within the same category condemned in the teaching of Jesus of the convention whereby one claimed corban. ${ }^{49}$ It was an avoidance scheme which the Lord criticized because it set aside the command of God. The neglect of a widow whether she lived at home or away from home would come under this condemnation, be she mother or grandmother, v.3.50

Second, the offenders were declared to be worse than an unbeliever, difloros, which is an exceedingly strong charge to bring against members of a Christian congregation, v.8.51 Why would this be said of the heads of households? It refers to the

\footnotetext{
48 It ought not to be assumed that the Christian families being addressed were either all nuclear families or all extended families. D.C. Barker has shown from a survey of Egyptian census returns that $53.4 \%$ were households with offspring and unmarried siblings, while the remainder were were either more than one nuclear family or relatives living with the nuclear family. New Docs 4 (1988) 89 and 93.

49 Mk.7.9-13.

50 This commandment certainly was interpreted to include more than parents by Philo, De Decalogo 165-7.

51 J.N.D. Kelly, op.cit. 115 'even pagans...recognize and set store by the obligations of children to parents'.
} 
fact that while holding the dowry, the head was not fulfilling his legal responsibilty to support the widow. Harrison notes that by remaining in her husband's house 'her sons were kbplol of the dowry, being charged with her maintenance out of it' ${ }^{52}$ Furthermore the preceding verse 'Command this so that they may be without reproach ( $\dot{\alpha} \in \epsilon \pi(\lambda \eta \mu \pi \tau o l)$ ', suggests a condemnation from society for such offensive behaviour which was in clear breach of the law, v.7.53

It would seem that at least some Christians were not supporting their widows whether these widows were residing in their households or possibly living elsewhere. As a result these widows were cast upon the strained financial resources of the church, even though Christians were bound to support them either on legal and/or religious grounds. It may well be that the church's general distribution to widows enabled some of the members of the Christian EkK $k \eta \sigma l a$ to conveniently evade providentia.

Epigraphic evidence from a Christian tombstone shows that Christian children of a subsequent generation followed the injunctions of 1 Timothy 5. "To well-deserving Rigina her daughter beautifully fashioned this tombstone. Rigina, mother, widow who remained a widow sixty years and never burdened the church; a univera who lived eighty years, five months, twenty-six days. ${ }^{\prime 54}$

\section{Providentia by the Believing Women}

In an endeavour to provide for the 'real' widow a believing woman, in $\pi\llcorner\sigma \tau \eta$, she must support her relatives who were widowed, v.16. To whom does this refer? F.C. Synge has argued that this verse means If any man or woman is converted and brings with him into the Church his household (with his sisters and cousins and aunts) he or she is to continue to support

\footnotetext{
52 A.R.W. Harrison, op.cit. 57.

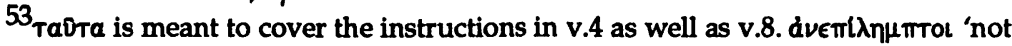
censured', 'not culpable'.

${ }^{54}$ E. Diehl, Inscriptiones Latinae Christianae Veteres (Berlin, Weidmann 1967) 1581 cited M. Lightman and W. Zeisel, 'Univira: An Example of Continuity and Change in Roman Society', Church History 46 (1977) 29.
} 
them and not burden the local congregation. ${ }^{55}$ A. Padgett argues "The false teachers were also urging these widows not simply to avoid the married life, but to abandon the support of their elderly mothers and grandmothers as well. ${ }^{\prime 56}$

The injunction however would appear to be an innovation which had neither legal nor ecclesiastical precedent. ${ }^{57}$ Christian women were being called upon to relieve the church of the extra mouths to feed who were their widowed relatives. There is no censure in v.16, but a call to shoulder responsibility for kinship relationships so that the church can adequately support widows who are without relatives.

Later evidence in the Christian church in Egypt shows that there were al mpos xripais, but it is not clear that they were relatives of the widows or women appointed by the church to care for them..$^{58}$

\section{Providentia for the 'Real' Widows}

There is great care taken in 5.3-16 to define precisely whom the church should support. The passage begins with the imperative addressed presumably to the one who has the oversight of the congregation viz. Timothy. He is to honour the widow who is a real widow i.e. to make sure that the church provides for her needs, v.3.59

\footnotetext{
55F.C. Synge, 'Studies in texts: 1 Timothy 5.3-16', Theology 108 (1968) 200-1. He accepts the reading $\pi\llcorner\sigma T d s \hbar \pi / \sigma \pi \hbar$ which is usually rejected, see B.M. Metzger, A Textual Commentary on the Greek New Testament (London and New York, United Bible Societies 1971) 642.

${ }^{56}$ A. Padgett, Wealthy Women at Ephesus: 1 Timothy 2:8-15 in Social Context', Interpretation 41 (1987) 21.

57 In the context it seems clear that 'having widows' = relations contra D.C. Verner, op.cit. 139 where he suggests that al mLotal were probably women like Tabitha in Acts 9:36f. who have taken widows under their protection. The verb 'to have' describes relatives of. 1 Cor 7:2. The argument of 1 Tim 5:3-16 is about the need to secure support of widows with kinship relationships in the congregation in order for the church to care for its real widows.

${ }^{58} \mathrm{E}$. Wipszycka, Les ressources et les activités des églises en Egypte du IV eau

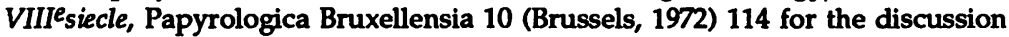
of 'les femmes chargers de s'occuper des veunes' and the evidence cited.

${ }^{59}$ Hence the use of a second person singular present imperative.
} 
The 'real' widow is defined in v.5a as a person without relatives, $\mu \epsilon \mu o \nu \omega \mu \epsilon \nu \eta{ }^{60}$ Because of the situation in which she finds herself she is like the widow in the O.T. who is cast upon God alone, $\eta \lambda \pi \leftarrow \kappa \in \nu$, and is therefore given to supplication and prayer day and night for her needs, v.5b. ${ }^{61}$ This is the 'real' widow for whom the church must take financial responsibility, because there is no other person to care for her.

She is described as being 'not less than sixty years of age'. The precise reason for restriction of age is uncertain. Had it been over fifty years, then it would have been explicable in the light of the fact that at least Roman law required a woman under fifty to remarry because she was still regarded as being of child bearing age and as a financial disincentive was precluded from obtaining any inheritance until she was that age. ${ }^{62}$ The reason may have simply been than women under sixty years were considered capable of working. ${ }^{63}$

She is also designated 'the wife of one husband'. If one adopts the interpretation that this refers to a woman who has married only once, then it poses problems for those young widows who obey the injunction in v.9 to remarry. In old age they could be disqualified from assistance fromt he church on the sole grounds that they are not 'a wife of one husband'. There is no reason to argue that there is here a prohibition on a second marriage. On the contrary women of marriagable age were instructed to do so. 64

${ }^{60}$ The perfect participle should be so interpreted and could translated as left all alone' i.e. without relations. P.G. Duncker, “"...quae vere viduae sunt"(1 Tim.5.3)', Angelicum 35 (1958) 121-38 for a discussion of distinguishing characteristics of the true widow in the O.T. and the Semitic world., and the real widow as $\mu \in \mu$ ovw $\mu k \nu \eta$.

${ }^{61}$ The perfect indicative also indicates her state or, better, her status, for she has none other than God in whom she can put her confidence to meet her material needs.

${ }^{62}$ A. Wallace-Hadrill, op.cit. 59.

${ }^{63}$ Our contemporary society sees no reason to justify the fixing of the age when a woman can receive a pension in some countries at the age of sixty other than she is not expected to work beyond that age. See $P$ Entreux 82 (221 BC) where a woman describes herself as 'a working woman' and obviously dependent upon her wages.

64 if kuds dubpos runt cannot mean that she was married once, but rather she did not commit adultery; cf. M. Dibelius and Hans Conzelmann, The Pastoral 
Her proven record of Christian good works is outlined. She is to be 'well attested for her good deeds, having brought up children, shown hospitality, washed the feet of the saints, relieved the afflicted and devoted herself to good in evey way.' vv.9-10.

By a process of elimiation the 'real' widow may be defined as being sixty year having neither children nor grandchildren nor a 'believing' woman to 'honour' her, a chaste Christian lady with true spirituality who has been given to good works.

\section{Disqualifying of Young Widows from providentia}

The discussion of the young widows in 5:11-15 contains descriptive, evaluative as well as prescriptive elements. An examination of all three helps in seeking to reconstruct the problem the young widows posed for the church.

The descriptive elements in vv.11b-12 are joined with $v .13$ by the use of the important connective $\alpha_{\mu \alpha} \delta \epsilon$ which denotes the coincidnece of two actions. ${ }^{65}$ The text indicates that the young widows now desire to remarry, v.11b. Had they taken a vow of univera in response to the false teaching of others in the church who forbade marriage and naturally remarriage? ${ }^{66}$ Had they dedicated themselves to God in prayer and supplication thus expressing confidence in the God who cares for the needy, and thus epitomizing the attitude of the godly widow? Whatever is meant by the expression it is

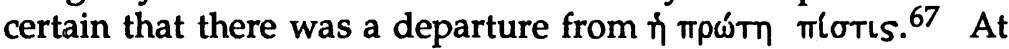
the same time, $d \mu \alpha$, there was a change in lifestyle with the emergence of the 'merry' widow of v.13 who is learning to be idle, going from house to house not for the benefit of the inhabitants, but simply to gossip and to discuss matters

Epistles, (Philadelphia, Fortress Press 1972) 75 who argue that it refers to chastity with whether married once or twice.

$65_{B D F} \# 425,2$.

${ }^{66} \mathrm{M}$. Lightman and W. Zeisel, op.cit. 119f. for a discussion of this in secular Roman society.

${ }^{67}$ A. Sand, 'Witwenstand und Ämterstrukturen in den urchristlichen Gemeinden', Bibel und Leben 12 (1971) 196 who argues that it refers to a vow of celibacy for devotion to God. Cf. also Rev 2:4 in ájám in $\pi \rho \omega \dot{m}$. 
inappropiate to the Christian profession. The nexus between vv.11b-12 and 13 is clearly related to the decision to remarry. The unbecoming behaviour may be linked to the way another marriage is being sought by the young widow.

The conduct of the widows is evaluated as 'running riot' of Christ, v.11b and thus condemned because of their abandoning of another way of living. ${ }^{68}$ It is explained that some of the widows have already committed apostacy, v.15.69

The solution is laid out in vv.11a and 14. In the latter case the use of ouv indicates that the prescription which follows is meant to remedy the unsatisfactory conduct which has been described previously. The young widows are to remarry, but there is an explication of what marriage is from a Christian perspective. They are to have children, rule their own households and conduct themselves in such a way that they do not bring the Christian faith into disrepute, i.e. 'give the enemy no occasion to revile us', v.14.

The refusal by the church to enrol young widows in v.11 must be judged in the light of the implications of the injunction to remarry in v.14. Such a call to the young widow rightly presupposes that the widow has a dowry. There must therefore have been a person in charge of it and thus legally responsible for her maintenance in her present status as a widow.

\section{Conclusions}

The motivation for proscribing distributions to some widows was not to subvert a charismatic claim to office by them in the church. ${ }^{70}$ There is no need to invoke a sociological perspective of 'equality and freedom' in order to argue that this passage sees the commencement of the erosion of the egalitarianism of the early stages of Christianity and the adoption of secular society's hierarchial and patriarchial structure. ${ }^{71}$ It

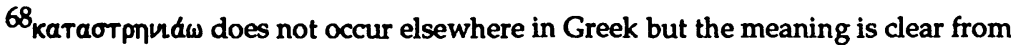
oTpnuldw = 'to run riot', 'become wanton' and the use of kaTd simply enforces it.

${ }^{69}$ D.C. Verner, op.cit. 165-6 cites similar expressions in 1 Tim 1:6, 6:20 and 2 Tim 4:4 and shows that the reference is to following false teachers.

${ }^{70}$ H.W. Bartsch, Die Anfänge: Evangelischer Rechtsbildungen: Studien zu den Pastoralbriefen (Hamburg, Herbert Reich 1965) 34.

${ }^{71}$ J.M. Bassler, op.cit. 39-40.
} 
is not correct to argue that 'predictably, the new Christian norms (including 1 Timothy 5:3-16) are much like the old defensive rules of Judaism' and constitute a post-Pauline regression of 'charismatic customs developed previously'.72

If it is felt that a twentieth-century value judgement must be brought to bear on the prescriptions for the support of widows in the early church in 1 Timothy 5:3-16, then the question must first be answered as to whether a local congregation would now be willing to draw on its resources to support widows per se if there existed financial provisions for them in secular society? Furthermore, would there be a willingness on the part of the church to assume responsibility for widows if there were children or grandchildren or female relatives in the same congregation who could support them? If it was a convention for young widows remarry, as it still is in some societies, would the governing body of that church support one who refused to do so especially if there were the requisite dowry, and the objection was based on a misfounded belief that there was a Christian proscription on marriage or remarriage?

1 Timothy 5:3-16 addresses the very important issue of the church and its members fulfilling the fifth command by honouring the widow. It is to be done by its members resuming the legal responsibility imposed by custody of the dowry, and by Christian women assuming responsibility for any widowed relatives. There is also be the care of widows for whom there is no legal responsibility as custodians of the dowry by children and grandchildren. Kinship relationships were still paramount in the Christian community. The young widow cannot draw upon the resources of the church, for she by means of her dowry must remarry in accordance with the conventions of the society of her day.

The overall concerns in redefining the eligibility of widows for financial support is also clearly spelt out. The church must be able to fulfil its role to care for the widow who is on her own and unable to care for herself. If she was a 'real' widow then the church would come to the rescue by showing

72B.J. Malina,.The New Testament World: Insights from Cultural Anthropology (Atlanta, John Knox Press 1981) 116. 
providentia to the 'widow of God'. ${ }^{73}$ The subsequent history of the church shows that this did happen, for there are extant records of the administration of its distribution which read Provide for Sophia, widow, from the coats you have one coat for good use'; 'to the widows...one double jar of wine'. ${ }^{74}$

${ }^{73}$ For the Christian inscription 'To the matron Octavia, a widow of God' see H.E. Fox, Christian Inscriptions in Ancient Rome (London, Morgan and Scott 1920) 45.

${ }^{74} P$ Wiscon 64 and P Oxy 1954 cited in New Docs 2 (1982) 192-3. 